\title{
BEZPIECZEŃSTWO PSYCHOLOGICZNE W ORGANIZACJI Z PERSPEKTYWY NAUK O ZARZĄDZANIU I JAKOŚCI
}

DOI: 10.33141/po.2020.09.01

Izabella Steinerowska-Streb
Przegląd Organizacji, Nr 9(968), 2020, s. 3-11 www.przegladorganizacji.pl ๔ Towarzystwo Naukowe Organizacji i Kierownictwa (TNOiK)

\section{Wprowadzenie}

W iele nowoczesnych organizacji traktuje obecnie kapitał ludzki jako filar w budowie swojej przewagi konkurencyjnej (Nafei, 2016, s. 86). Organizacje te starają się $\mathrm{w}$ różny sposób rozbudzić potencjał, jaki tkwi w ich pracownikach. Część z nich inwestuje w rozwój wiedzy pracowników lub w coaching. Inne motywują zespoły pracownicze, stawiając im różne wyzwania. Jeszcze inne stosują zarządzanie talentami (PwC, 2014). Są też takie, które starają się tworzyć bezpieczeństwo psychologiczne $\mathrm{w}$ organizacji. Bezpieczeństwo to oddziałuje bowiem pozytywnie na aktywność pracowników, sprzyja ich kreatywności, zaangażowaniu w realizację celów organizacji, wzbudza w nich chęć dzielenia się informacjami, zachęca ich do identyfikowania wad $\mathrm{w}$ organizacji, realizacji projektów czy też rozwoju produktu (Bass i in., 2008; Boucher i in., 2018; O’Donovan, McAuliffe, 2020).

Bezpieczeństwo psychologiczne w organizacji najczęściej definiuje się jako wspólne przekonanie jednostek co do tego, czy bezpieczne jest podejmowanie interpersonalnego ryzyka w miejscu pracy (Newman i in., 2017). Problematyka tak rozumianego bezpieczeństwa psychologicznego w organizacji zaczęła zyskiwać na popularności pod koniec XX wieku. Obecnie koncepcję tę z powodzeniem wykorzystują w praktyce wiodące korporacje. W Polsce bezpieczeństwo psychologiczne $\mathrm{w}$ organizacji jest jednak ciągle zagadnieniem mało znanym. Pomimo iż na polskim rynku można znaleźć organizacje, które wdrożyły już koncepcję bezpieczeństwa psychologicznego, to w polskiej literaturze $\mathrm{z}$ zakresu zarządzania problematyka ta zasadniczo nie jest obecna. Mając na względzie tę lukę, celem bieżącego badania stało się przedstawienie kierunków badań nad bezpieczeństwem psychologicznym $\mathrm{w}$ organizacji $\mathrm{z}$ perspektywy dyscypliny nauk o zarządzaniu i jakości oraz zaprezentowanie obecnego stanu wiedzy na tej płaszczyźnie. Podjęte postępowanie badawcze miało doprowadzić do znalezienia odpowiedzi na następujące pytania:

1. Jakie są główne wątki podejmowane w badaniach nad bezpieczeństwem psychologicznym w organizacji z perspektywy dyscypliny nauk o zarządzaniu i jakości?

2. Jaki jest wpływ bezpieczeństwa psychologicznego na organizacje w świetle badań realizowanych na płaszczyźnie nauk o zarządzaniu i jakości?
3. Jakie są mechanizmy stojące $u$ podstaw bezpieczeństwa psychologicznego $\mathrm{w}$ organizacjach $\mathrm{z}$ perspektywy dyscypliny nauk o zarządzaniu i jakości?

\section{Bezpieczeństwo psychologiczne w organizacjach jako przedmiot badań}

B ezpieczeństwo psychologiczne w organizacji stało się przedmiotem zainteresowania badaczy w latach 60 . XX wieku. Początków rozwoju tej koncepcji można dopatrywać się $\mathrm{w}$ badaniach nad zmianami organizacyjnymi prowadzonymi przez E.W. Schein i W.G. Bennis (1965), które ujawniły potrzebę stworzenia bezpieczeństwa psychologicznego dla jednostek mających sprostać ryzyku związanemu z wdrożeniem zmian (Edmondson, Lei, 2014, s. 23-24).

Współczesna koncepcja bezpieczeństwa psychologicznego w organizacji została opracowana przez W.A. Kahna (1990). Zdefiniował on bezpieczeństwo psychologiczne w organizacji, odnosząc się do odczuć członków zespołu i postrzegania przez jednostki swoich zachowań przez pryzmat negatywnych konsekwencji, które mogą z tych zachowań wyniknąć dla ich wizerunku, pozycji lub kariery (Kahn, 1990, s. 708). Istota bezpieczeństwa psychologicznego tkwi według W.A. Kahna w tym, aby pracownik był sobą bez negatywnych skutków dla własnego statusu i swojej przyszłości w organizacji. Zwolennikami takiego podejścia do bezpieczeństwa psychologicznego w organizacji byli S.P. Brown i T.W. Leigh (1996, s. 358), którzy zbadali oddziaływanie klimatu bezpiecznego psychologicznie na pracowników. Wyniki tych badań ujawniły, że psychologicznie bezpieczny klimat przyczynia się do wzrostu zaangażowania pracowników w wykonywane obowiązki i wzmożonego ich wysiłku w realizację zadań. Efektem tego jest poprawa wydajności ich pracy.

U podstaw współczesnej koncepcji bezpieczeństwa psychologicznego stoi założenie, że poczucie bezpieczeństwa psychologicznego jednostki w miejscu pracy kształtuje się przez ciągłe interakcje interpersonalne między bliskimi współpracownikami. Zwolennicy tej koncepcji twierdzą, że interakcje interpersonalne są wyjściowym źródłem ryzyka dla jednostek w miejscu pracy. W ich mniemaniu człowiek z natury czuje się bowiem nieswojo, 
gdy przedstawia współpracownikom swoje pomysły i idee. Zdaniem A.C. Edmondson (2004, s. 242), dzieje się tak dlatego, że jednostki, poszukując w swoim otoczeniu informacji zwrotnych, narażają się jednocześnie na krytykę.

Zgodnie z koncepcją bezpieczeństwa psychologicznego $\mathrm{w}$ organizacji, gdy pracownik czuje się bezpieczny psychologicznie, wzrasta jego poczucie pewności, że grupa lub zespół pracowniczy nie będzie go karać za prawdziwe wyrażanie swoich myśli. Dzięki bezpieczeństwu psychologicznemu zmniejszają się więc obawy pracownika związane z groźbą zawstydzenia, ośmieszenia czy też odrzucenia, gdy mówi on o swoich wątpliwościach, pytaniach lub błędach (Edmondson, 1999). W konsekwencji pracownik jest skłonny do intensywnego poszukiwania informacji zwrotnej, dzielenia się informacjami, a także do podejmowania różnych ryzykownych interpersonalnie zachowań (Pearsall, Ellis, 2011).

Chociaż bezpieczeństwo psychologiczne dotyczy jednostki, to kształtuje się ono przede wszystkim na poziomie zespołu (Newman i in., 2017). Jak dowodzą badania T.C. Wu, C.W. Liu i M.C. Lu (2007), bezpieczeństwa psychologicznego w organizacji można doszukiwać się również na poziomie organizacji. Zasady i praktyki obowiązujące w organizacji, jako całości, mogą bowiem narzucać pracownikom określone, powszechnie pożądane i akceptowane schematy zachowań, zgodne lub niezgodne $\mathrm{z}$ ideą bezpieczeństwa psychologicznego. D. Newman i inni (2017) twierdzą jednak, że bezpieczeństwo psychologiczne na poziomie organizacji występuje jedynie wtedy, gdy organizacja jest mała. Wyniki ich badań wskazują, że w większych organizacjach bezpieczeństwo psychologiczne ma głównie znaczenie na poziomie zespołu

Bezpieczeństwo psychologiczne rozpatruje się zatem na poziomie jednostki, zespołu, a także na poziomie organizacji. Analizy na poziomie jednostki koncentrują się na percepcji bezpieczeństwa psychologicznego z punktu widzenia pojedynczego pracownika lub menedżera. $\mathrm{W}$ pozostałych analizach - na poziomie zespołu lub organizacji - dokonuje się natomiast agregacji jednostkowych opinii na temat bezpieczeństwa psychologicznego. Zdaniem A.C. Edmondson i Z. Lei (2014), agregacja na poziomie organizacji jest jednak dyskusyjna. Autorzy za wątpliwe uważają, że pomiędzy wszystkimi członkami każdej organizacji istnieje wysoki poziom zgodności warunkujący występowanie bezpieczeństwa psychologicznego.

\section{Metoda badawcza}

$\mathbf{R}$ ealizacja wyznaczonego celu została osiągnięta w oparciu o studia literaturowe (desk research) obejmujące lata 1994-2020 (analiza została zakończona 26 lipca 2020 roku). W klasyfikacji Milesa i Hubermana (Flick, 2012, s. 56) projekt zaliczono do tzw. projektów „ścisłych”, co przesądziło o celowym doborze próby, która jest posłuszna logice generalizacji. Za zbiór materiałów, które stanowią korpus empirycznych przykładów umożliwiających jak najbardziej dogłębną eksplorację tematu, uznano bazę ISI Web of Science (WoS). Baza ta jest bowiem podstawowym źródłem publikacji, które nadają prym w światowej debacie w dyscyplinie nauki o zarządzaniu i jakości (Dionisio, de Vargas, 2020).
Studiami literaturowymi objęto wszystkie anglojęzyczne, indeksowane, przyporządkowane do sekcji zarządzanie (management) oraz biznes (business) artykuły znajdujące się w bazie WoS w obrębie WoS Core Collection pod hasłem tematycznym psychological safety (bezpieczeństwo psychologiczne). Wyszukiwanie nie było zawężone co do czasu ukazania się artykułów ani też co do powszechnej dostępności artykułu (open access). W dniu 26.07.2020 r. dodentyfikowano 495 takich pozycji, wśród których najstarsza została opublikowana w 1994 roku (była to wówczas jedyna pozycja o tej tematyce występująca w bazie WoS). W wyselekcjonowanym zbiorze najstarszy artykuł pochodził z 1994 roku, a najmłodszy z 2020 roku. Uwzględniając cele bieżącego badania $z$ dalszej analizy wyeliminowano: 1) artykuły, w których bezpieczeństwo psychologiczne stanowiło jedynie wątek poboczny; 2) artykuły, w których prowadzone były metaanalizy ${ }^{1}$. Teksty tak wyselekcjonowanych 56 artykułów umieszczono w programie QDA Miner. Następnie, podobnie jak w innych tego typu postępowaniach badawczych (Dionisio, de Vargas, 2020), dokonano przeglądu i kodowania ich abstraktów oraz konkluzji. Opierając się na wytycznych dotyczących kodowania tematycznego i kategoryzacji danych zaproponowanych przez G. Gibbsa (2011) i z uwzględnieniem przyjętych celów badania utworzono listę kodów bez uprzedniej konceptualizacji (kodowanie na podstawie danych). W trakcie czytania kodowano poszczególne fragmenty tekstu, a gdy powstające w tym procesie kody ulegały rozbudowaniu, tworzono dla nich kategorie nadrzędne. Zakodowane elementy tekstów stanowiły podstawę obliczeń wykonanych $\mathrm{w}$ programie QDA Miner. W ich efekcie zidentyfikowano główne wątki podejmowane $\mathrm{w}$ badaniach nad bezpieczeństwem psychologicznym w organizacji w naukach o zarządzaniu i jakości (rys. 1). Do rozpoznania najczęstszych wątków współwystępujących wykorzystano macierz podobieństwa oraz indeks podobieństwa Jaccarda. Współczynnik ten zawiera się w przedziale pomiędzy 0 i 1, przy czym 1 oznacza najwyższe podobieństwo, a 0 najniższe podobieństwo (Marczak, 2015). Im wyższe były wartości tego współczynnika, tym bardziej za nierozerwalne uznano współwystępujące wątki.

\section{Wyniki badania}

$\mathbf{N}$ a podstawie przeprowadzonej analizy zidentyfikowano cztery główne obszary badań nad bezpieczeństwem psychologicznym w organizacji na płaszczyźnie nauk o zarządzaniu i jakości. Obejmują one: (1) istotę bezpieczeństwa psychologicznego (koncepcja, determinanty, pomiar); (2) obszary występowania bezpieczeństwa psychologicznego $\mathrm{w}$ organizacjach (poziom organizacyjny, grupowy, indywidualny); (3) wpływ bezpieczeństwa psychologicznego na organizację (wydajność, innowacyjność, kreatywność, zachowania członków zespołu, efektywność zespołów, uczenie się przez porażkę, dzielenie się informacjami, zaufanie); (4) mechanizmy stojące u podstaw bezpieczeństwa psychologicznego w organizacjach 
(teoria aktywacji cech osobowości, teoria przetwarzania informacji społecznej, teoria wymiany społecznej, teoria zachowania zasobów, ukryta teoria głosu). Spośród wskazanych wątków najczęściej badano istotę bezpieczeństwa psychologicznego i jego wpływ na organizację. Prowadzone analizy głównie dotyczyły poziomu grupy/zespołu, przy czym problematyka badań na tej płaszczyźnie koncentrowała się przede wszystkim na wydajności w organizacji lub czynnikach wpływających na bezpieczeństwo psychologiczne (rys. 1 i 2). W badaniach dotyczących wpływu bezpieczeństwa psychologicznego na organizacje oprócz wydajności najczęściej zajmowano się dzieleniem się informacjami i kreatywnością. Natomiast koncepcja i determinanty bezpieczeństwa psychologicznego stanowiły przedmiot zainteresowań badaczy w niemal co czwartym artykule.

Badania dotyczące bezpieczeństwa psychologicznego na poziomie grupy oraz wydajności w organizacjach lub też determinant bezpieczeństwa psychologicznego w szerszej perspektywie łączono z koncepcją bezpieczeństwa psychologicznego w organizacji i z ukrytą teorią głosu. Natomiast na poziomie jednostki bezpieczeństwo psychologiczne badano głównie wspólnie $z$ dzieleniem się informacjami. Z szerszej perspektywy wszystkie wymienione wątki łączono również $\mathrm{z}$ uczeniem się przez porażkę (rys. 2).

Gdy w badaniach nad bezpieczeństwem psychologicznym poruszane były kwestie dotyczące kreatywności, to przede wszystkim łączono je $\mathrm{z}$ teorią przetwarzania informacji społecznej oraz z zaufaniem. Natomiast gdy bezpieczeństwo psychologiczne było eksplorowane w kontekście innowacyjności, to wiązano je $\mathrm{z}$ teorią wymiany społecznej, a także z zachowaniami członków w organizacji.
W szerszym ujęciu wątki te rozpatrywano na poziomie organizacyjnym i łączono także $\mathrm{z}$ teorią zachowania zasobów.

Spośród wszystkich zidentyfikowanych wątków w prowadzonych badaniach najrzadziej odnoszono się do teorii aktywacji cech osobowości oraz do pomiaru bezpieczeństwa psychologicznego w organizacjach (rys. 2).

W obrębie powiązań występujących pomiędzy poszczególnymi wątkami poruszanymi w analizowanych badaniach nie było wątków, które zawsze współwystępowały łącznie (tab. 1). Najsilniejsze współwystępowanie wątków stwierdzono w przypadku analizy bezpieczeństwa psychologicznego na poziomie grupowym. Gdy eksplorowano zagadnienia dotyczące bezpieczeństwa psychologicznego na poziomie grupowym, to w przybliżeniu w co czwartym badaniu wątek ten łączono $\mathrm{z}$ czynnikami determinujący$\mathrm{mi}$ bezpieczeństwo psychologiczne $\mathrm{w}$ organizacji. $\mathrm{Z}$ podobną częstotliwością w badaniach nad bezpieczeństwem psychologicznym na poziomie grupowym zajmowano się również wydajnością $\mathrm{w}$ organizacjach. Tymczasem gdy zgłębiano koncepcję bezpieczeństwa psychologicznego, to $\mathrm{w}$ co piątym badaniu wątek ten łączono $\mathrm{z}$ ukrytą teorią głosu lub też z teorią przetwarzania informacji społecznej, albo $\mathrm{z}$ zagadnieniami rozpatrywanymi na poziomie grupowym. Współwystępowanie pozostałych wątków było natomiast słabsze (tab. 1).

\section{Wpływ bezpieczeństwa psychologicznego na organizacje}

Wniki przeprowadzonej analizy wskazują, że jednym z głównych wątków badawczych poruszanych w badaniach nad bezpieczeństwem psychologicznym

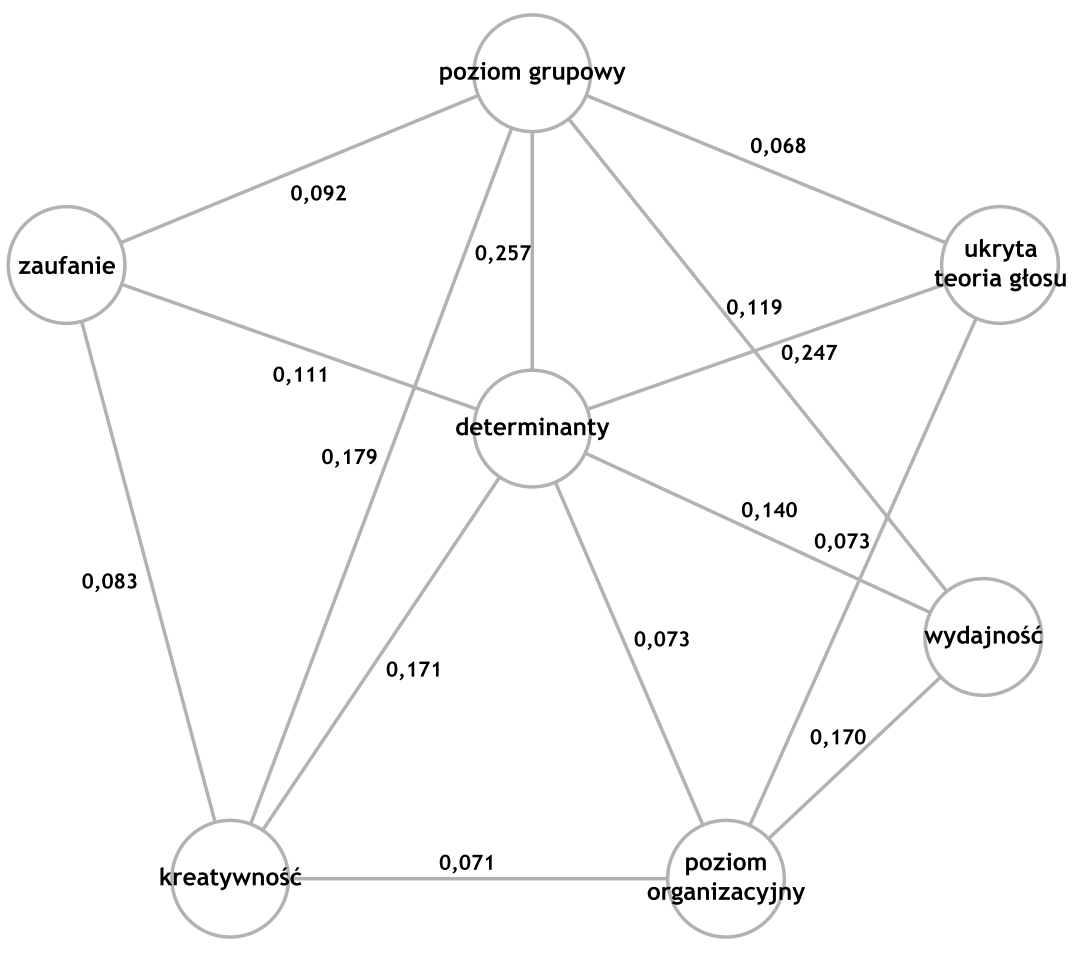

Rys. 1. Podstawowe wątki poruszane w analizowanych artykutach Źródto: opracowanie wtasne 


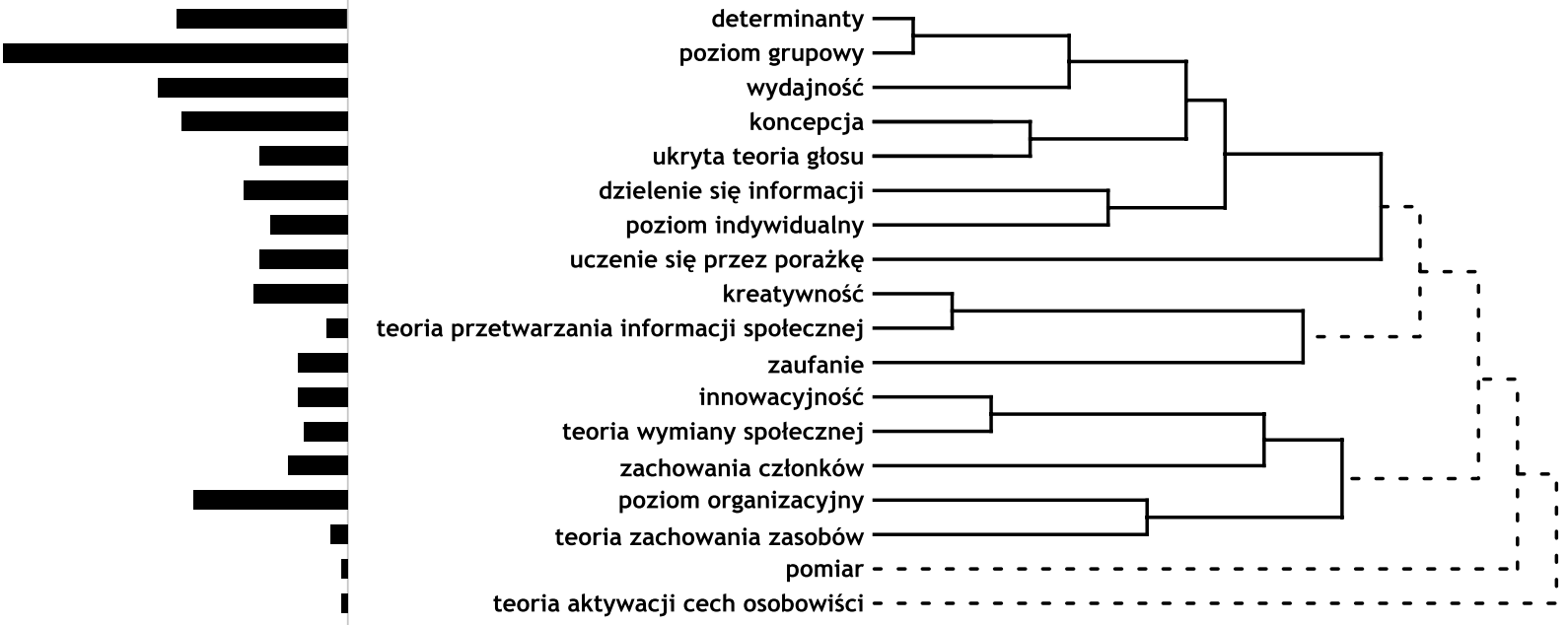

Rys. 2. Powiązania występujące $w$ badaniach dotyczących bezpieczeństwa psychologicznego, zidentyfikowane z wykorzystaniem wspótczynnika podobieństwa Jaccarda

Źródło: opracowanie wtasne

w organizacji w obrębie nauk o zarządzaniu i jakości jest wpływ bezpieczeństwa psychologicznego na organizacje. Przegląd literatury dotyczący tej problematyki wskazuje, że bezpieczeństwo psychologiczne oddziałuje na funkcjonowanie organizacji wielopłaszczyznowo. Dowodzi się, że bezpieczeństwo psychologiczne w organizacji ma kluczowe znaczenie w kształtowaniu zachowań jednostek w obrębie organizacji i wspomaga proces skutecznego uczenia się przez porażkę (Carmeli, Gitell, 2009). W szczególności bezpieczeństwo psychologiczne ma wpływ na odgrywanie przez pracowników przypisanych im ról, a także na podejmowanie przez pracowników dodatkowych, dobrowolnych aktywności, wykonywanych dla dobra kolektywu.

Badania R. Karka i A. Carmeli (2009) wykazały, że odczuwanie bezpieczeństwa psychologicznego przez pojedynczego pracownika wywołuje $\mathrm{w}$ nim poczucie witalności. Taki pracownik jest pełny zapału, co zwiększa jego kreatywność, która przejawia się w generowanych przez niego pomysłach.

$\mathrm{Na}$ występowanie związków pomiędzy bezpieczeństwem psychologicznym i kreatywnością pracowników zwracają uwagę również M. Bass i inni (2008). Z ich badań wynika, że kiedy lęk przed porażką w zespole pracowniczym jest niski, wówczas członkowie zespołu nie obawiają się negatywnych konsekwencji nieudanych prób twórczych, a także chętniej podejmują ryzyko i szybciej myślą. Skutkuje to wzrostem kreatywności w obrębie zespołu pracowniczego. Poprzez zmniejszenie poziomu lęku pracowników przed porażką bezpieczeństwo psychologiczne $\mathrm{w}$ organizacji oddziałuje więc na redukcję ryzyka postrzeganego przez pracowników i wpływa pozytywnie na kreatywność pracowników (Bass i in., 2008), którą J. George i J. Zhou (2007) zaliczają do zachowań ryzykownych.

Związek bezpieczeństwa psychologicznego z kreatywnością tłumaczy się również łatwiejszą wymianą informacji, dzięki której jednostki posiadają więcej wiedzy inspirującej ich do opracowywania nowych pomysłów.
Badania na tej płaszczyźnie prowadzili E. Siemsen i inni (2009). Dowiedli oni, że bezpieczeństwo psychologiczne $\mathrm{w}$ organizacji motywuje pracowników do dzielenia się wiedzą, a także wykazali, że wpływ bezpieczeństwa psychologicznego na dzielenie się wiedzą jest moderowany poziomem zaufania. $\mathrm{Z}$ ich badań wynika, że większe zaufanie zmniejsza siłę związku między bezpieczeństwem psychologicznym a wiedzą.

$\mathrm{Na}$ związki pomiędzy bezpieczeństwem psychologicznym i zaufaniem oraz ich wpływem na organizację wskazują również badania A.C. Edmondson (2004). Wynika $\mathrm{z}$ nich, iż są to komplementarne zjawiska, które mogą wpływać na różne wyniki zachowań pracowników, a tym samym na aktywność organizacji, w których są zatrudnieni (Edmondson, 2004).

A. Carmeli i J.H. Gitell (2009) badali natomiast związki między bezpieczeństwem psychologicznym $\mathrm{w}$ organizacji i uczeniem się przez porażkę. Wyniki tych badań dowiodły, że wspólne cele, wiedza i wzajemny szacunek w zespole zwiększają bezpieczeństwo psychologiczne, a tym samym umożliwiają członkom zespołu pracowniczego uczenie się na błędach. Badania te pokazały, że istnieje pozytywny związek pomiędzy bezpieczeństwem psychologicznym a uczeniem się przez porażkę, a także iż bezpieczeństwo psychologiczne umożliwia stawianie grupom ambitnych celów i pracę nad nimi poprzez uczenie się.

Występowanie związków pomiędzy bezpieczeństwem psychologicznym i skutecznością zespołów zostało natomiast dowiedzione przez badaczy z firmy Google podczas realizacji projektu o akronimie ARISTOLE. W tym badaniu skuteczność zespołu mierzono na cztery różne sposoby. Brano pod uwagę: (1) ocenę wyników zespołu, (2) ocenę zespołu przez jego lidera, (3) ocenę zespołu przez jego członka, (4) kwartalne wyniki sprzedaży. Wnioski z tego badania wskazują, że skuteczność zespołu nie zależy od składu zespołu, lecz od tego, jak jego członkowie pracują razem. Do najważniejszych czynników, które kształtowały tę zależność, zaliczono w pierwszej kolejności bezpieczeństwo psychologiczne (Bariso, 2018). 


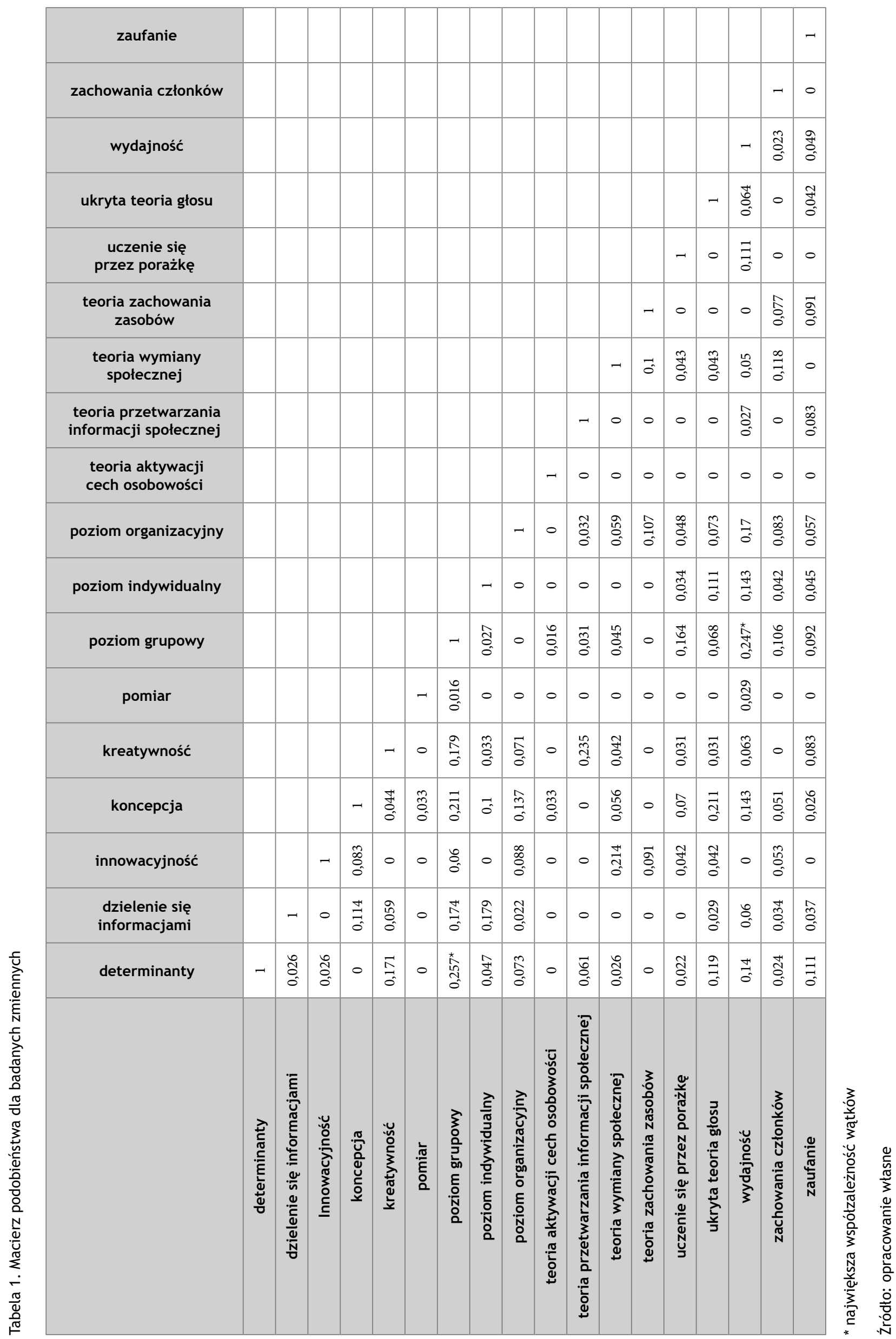


Bezpieczeństwo psychologiczne wpływa także na wydajność organizacji. Badania na tej płaszczyźnie prowadzili C.C. Huang i P.C. Jiang (2012). W ich świetle wpływ ten jest pośredni i pojawia się on zarówno na poziomie jednostki, jak i na poziomie grupy. Autorzy ci zidentyfikowali, że podstawy tego związku tkwią w uczeniu się zespołu. Innych przyczyn oddziaływania bezpieczeństwa psychologicznego na wzrost wydajności w organizacjach upatrują M. Baer i M. Frese (2003). Przeprowadzone przez nich badania wykazały, że na występowanie zależności pomiędzy bezpieczeństwem psychologicznym a wydajnością firmy pośredni wpływ mają innowacje procesowe.

Przegląd literatury przedmiotu wskazuje zatem, że bezpieczeństwo psychologiczne w organizacji ma pozytywny i znaczący wpływ na organizacje. Występuje on na poziomie zarówno organizacji, zespołu, jak i na poziomie indywidualnym. Najważniejsze z efektów wpływu bezpieczeństwa psychologicznego na organizacje na poszczególnych jej poziomach zostały przedstawione w raporcie „Psychological Safety: An Essential Constituent of COMPASS. Directions" przez A. Bouchera i innych (2018) (tab. 2).

Szczegółowa analiza przytoczonych wyników badań empirycznych wskazuje dodatkowo, że na różnych poziomach organizacji różnie kształtują się relacje występujące pomiędzy bezpieczeństwem psychologicznym $\mathrm{w}$ organizacji a dzieleniem się informacjami, uczeniem się, kreatywnością, innowacyjnością oraz wydajnością/ efektywnością. Rezultaty analizowanych badań wskazują mianowicie, że na poziomie indywidualnym bezpieczeństwo psychologiczne oddziałuje bezpośrednio na dzielenie się informacją, a pośrednio na kreatywność. $\mathrm{Na}$ poziomie zespołu bezpośredni wpływ bezpieczeństwa psychologicznego występuje natomiast w odniesieniu do dzielenia się informacją i uczenia się. Ponadto na poziomie zespołu bezpieczeństwo psychologiczne pośrednio oddziałuje na kreatywność i efektywność organizacji oraz ma ono moderujący wpływ na innowacyjność organizacji. Tymczasem na poziomie organizacji bezpieczeństwo psychologiczne wpływa bezpośrednio na dzielenie się informacją i uczenie się oraz pośrednio na efektywność organizacji. Na tym poziomie bezpieczeństwo psychologiczne jest również moderatorem innowacyjności i efektywności organizacji.

\section{Mechanizmy stojące u podstaw bezpieczeństwa psychologicznego w organizacjach}

W obrębie nauk o zarządzaniu i jakości poszukuje się również mechanizmów, które stoją u podstaw bezpieczeństwa psychologicznego $\mathrm{w}$ organizacjach. Związki występujące na tej płaszczyźnie tłumaczą różne teorie, a w szczególności tzw. ukryte teorie głosu (Implicite Voice Theories, IVTs). Na gruncie tych teorii zakłada się, że milczenie pracowników (brak werbalizacji opinii i spostrzeżeń przez pracowników $\mathrm{w}$ organizacji) może wynikać $\mathrm{z}$ ich świadomej i przemyślanej decyzji o niezabraniu głosu (Detert, Edmondson, 2011). Może ono być także rezultatem „bycia uciszonym” przez otoczenie lub też może być efektem tzw. milczenia ugodowego (Pacheco i in., 2015). W tym ostatnim przypadku pracownicy dzielą przekonanie, że zabieranie głosu w organizacji nie ma sensu i przyjmują postawę podległości i rezygnacji. Ukryte teorie głosu dotyczą właśnie tego zjawiska - milczenia ugodowego w organizacji i jego psychologicznych mechanizmów.

Ukryte teorie głosu odnoszą się do przekonań na temat możliwych zagrożeń wynikających $\mathrm{z}$ wypowiedzi pracowników przed przełożonymi. Przekonania te są pochodną wpływów otoczenia na jednostkę lub też są one formułowane w oparciu o indywidualne doświadczenia jednostki. Do aktywizacji tych przekonań dochodzi zazwyczaj podświadomie. Wiedza, którą jednostka posiada na temat konsekwencji związanych z zabieraniem głosu, wpływa zatem na takie decyzje jednostki, które dają jej poczucie psychologicznej kontroli nad zdarzeniami, ochrony siebie i grupy oraz utrzymywania relacji z innymi (Adamska, 2016).

Wpływ bezpieczeństwa psychologicznego w organizacji na pracowników tłumaczą również teorie stresu i ludzkiej motywacji, a w szczególności teoria zachowania zasobów (Conservation of Resources, COR). W teorii tej zakłada się, że dla jednostki utrata zasobów jest niewspółmiernie bardziej odczuwalna od zysku (Hobfoll, 1989). W tym świetle źródłem braku bezpieczeństwa psychologicznego w organizacji może być stres wynikający z połączenia dwóch czynników. Jednym $z$ nich jest subiektywne odczuwanie przez pracownika określonego zdarzenia jako zmniejszającego lub przekraczającego jego zasoby osobiste, takie

Tabela 2. Podstawowe efekty wynikające z bezpieczeństwa psychologicznego $\mathrm{w}$ organizacji na poziomie organizacji, zespołu i na poziomie indywidualnym

\begin{tabular}{|c|l|}
\hline \multicolumn{1}{|c|}{ Poziom } & \multicolumn{1}{c|}{ Efekty wynikające z bezpieczeństwa psychologicznego na danym poziomie } \\
\hline indywidualny & $\begin{array}{l}\text { Środowisko pracy, w którym dana osoba czuje się psychologicznie bezpieczna, wzbudza zaufanie, a zatem pobudza } \\
\text { kreatywność, proaktywność i chęć dzielenia się informacjami z innymi. Pracownicy częściej aktywnie angażują się } \\
\text { w dzielenie się informacjami ze współpracownikami i stwarzają okazję do produktywnej dyskusji na temat ulepszeń. }\end{array}$ \\
\hline grupowy & $\begin{array}{l}\text { Bezpieczeństwo psychologiczne prowadzi do zespołowego uczenie się i ciągłych innowacji rozwijanych poprzez } \\
\text { konflikt zadań i współpracę w grupie. Pozwala to członkom zespołu uczyć się na błędach i incydentach oraz zachęca } \\
\text { ich do innowacyjnych zmian. }\end{array}$ \\
\hline organizacyjny & $\begin{array}{l}\text { Bezpieczeństwo psychologiczne prowadzi do budowania relacji między pracodawcą a pracownikiem i rozwoju } \\
\text { sieci wsparcia w organizacji. Ułatwiona jest tam wymiana wiedzy i powstaje środowisko, w którym osoby czują się } \\
\text { bezpiecznie, podejmując ryzyko interpersonalne. }\end{array}$ \\
\hline
\end{tabular}

Źródło: Boucher i in., 2018, s. 2 
jak: poczucie kontroli, własnej skuteczności czy reputacji. Drugi czynnik tworzą natomiast obiektywne lub faktyczne okoliczności środowiskowe, które prowadzą do wyczerpania zasobów osobistych pracownika. Jeżeli czynniki te zaistnieją i pracownik odczuje, że jego zasoby osobiste są zagrożone, to przy niedostatecznych zasobach społecznych (np. wsparcie emocjonalne) pracownik może instynktownie przyjąć pewien wzorzec zachowania, którym może być milczenie (Alvaro i in., 2010).

Zależności występujące pomiędzy wynikami pracy a bezpieczeństwem psychologicznym $\mathrm{w}$ organizacji wyjaśnia natomiast teoria aktywacji cech osobowości (Trait Activation Theory, TAT). W tej teorii centralne znaczenie ma aktywacja cech jednostki, rozumiana jako proces interakcyjny prowadzący do ekspresji cech osobowości jednostki w miejscu pracy. Według teorii TAT, ekspresja behawioralna tych cech następuje $\mathrm{w}$ reakcji na bodźce (wskazówki sytuacyjne) występujące w otoczeniu, w którym jednostka funkcjonuje. Bodźcem takim może być nagroda w postaci satysfakcji (Newman i in., 2017). Teoria TAT tłumaczy, że środowisko o wysokim poziomie bezpieczeństwa psychologicznego dostarcza jednostkom wskazówek i zapewnia im możliwości wyrażania swoich cech. Tym samym środowisko to wzmacnia predyspozycje jednostek do działania proaktywnego, zawartego w ich cechach osobowościowych, takich jak ekstrawersja, osobowość proaktywna, orientacja na cel i uczenie się. W efekcie zwiększa się prawdopodobieństwo zaangażowania jednostki w takie zachowania, jak zabieranie głosu lub dzielenie się informacjami (Newman i in., 2017).

Bezpieczeństwo psychologiczne $\mathrm{w}$ organizacji uzasadnia się również teoria wymiany społecznej (Social Exchange Theory, SET). W teorii tej podstawową rolę nadaje się zaufaniu. SET zakłada, że lojalne, ufne i zaangażowane relacje rozwijają się z czasem, przy założeniu że są one obustronne. Ponadto w tej teorii za bardziej prawdopodobne uważa się, iż powtórzy się interakcja wywołująca aprobatę innej osoby niż interakcja wywołująca dezaprobatę (Dunne, Greenwald, 2014). W świetle SET odpowiedzialne działania jednej strony doprowadzają do wzajemnych działań drugiej strony. Praktyki wspierające i pozytywne relacje w środowisku pracy mogą zatem prowadzić pracowników do odwzajemnionej odpowiedzi w postaci pozytywnych wyników pracy (Newman i in., 2017). Teoria wymiany społecznej jest wykorzystywana do wyjaśnienia związku pomiędzy czynnikami determinującymi wysoki poziom bezpieczeństwa psychologicznego w organizacji a wynikami organizacji. Teoria ta nie zapewnia jednakże szczegółowego i całościowego zrozumienia podstawowych procesów, dzięki którym rozwija się bezpieczeństwo psychologiczne (Dunne, Greenwald, 2014).

\section{Podsumowanie}

$\mathbf{N}^{2}$ płaszczyźnie nauk o zarządzaniu i jakości bezpieczeństwo psychologiczne w organizacji postrzega się coraz częściej jako jeden z kluczowych czynników prowadzących do ciągłej poprawy jakości w organizacji, rozwoju produktów oferowanych przez organizacje, implementacji nowych koncepcji, identyfikowania potencjalnych wad organizacji, a także efektywnej realizacji projektów. Badania prowadzone na tej płaszczyźnie dowodzą, że bezpieczeństwo psychologiczne w organizacji oddziałuje pozytywnie na pracę zespołową, uczenie się w zespole, dzielenie się informacjami, aktywne zachowania pracowników, a także na efektywność organizacji. Takie wyniki badań stanowią zatem istotny argument przemawiający za implementacją koncepcji bezpieczeństwa psychologicznego przez organizacje postrzegające swoich pracowników jako kapitał, który może stanowić źródło ich konkurencyjności i innowacyjności. Mając na względzie wielopłaszczyznowe oddziaływanie bezpieczeństwa psychologicznego na organizacje, celowe wydaje się również dalsze zgłębianie wiedzy w tym obszarze. Dzięki kolejnym badaniom znajomość zagadnień dotyczących bezpieczeństwa psychologicznego w organizacjach będzie wzrastać, a zdobyte informacje będzie można wykorzystać w praktyce gospodarczej. Badania, które dotąd na ten temat zrealizowano, pozostawiają jeszcze wiele luk poznawczych wartych eksploracji. Nieznane są bowiem jeszcze wszystkie czynniki determinujące bezpieczeństwo psychologiczne w organizacji ani rodzaj ich oddziaływania na klimat psychologicznie bezpieczny. Przykładowo niejasne są skutki interwencji liderów w kształtowanie się bezpieczeństwa psychologicznego w organizacjach. Cały czas nie zgłębiono także wszystkich rezultatów, do jakich bezpieczeństwo psychologiczne prowadzi na różnych poziomach organizacji.

\section{dr hab. Izabella Steinerowska-Streb, prof. uczelni Uniwersytet Ekonomiczny w Katowicach Kolegium Ekonomii \\ ORCID: 000-0001-5379-5730 \\ e-mail: streb@ue.katowice.pl}

\section{Przypis}

1) Ze względu na liczebność analizowanego zbioru artykułów nie zamieszczono ich w bibliografii.

\section{Bibliografia}

[1] Adamska K. (2016), Milczenie i przełamywanie milczenia $w$ organizacji, „Roczniki Psychologiczne/Annals of Psychology", Vol. 19, Nr 1, s. 75-88.

[2] Alvaro C., Lyons R.F., Warner G., Hobfoll S.E., Martens P.J., Labonte R. (2010), Conservation of Resources Theory and Research Use in Health Systems, „Implementation Science”, Vol. 5, No. 79, pp. 1-20.

[3] Baas M., De Dren C.K.W., Nijstad A.B. (2008), A. Meta-Analysis of 25 Years of Mood-Creativity Research: Hedonic Tone, Activation, or Repulatory Focus? „Technological Bulletin", Vol. 134, No. 6, pp. 779-806.

[4] Baer M., Frese M. (2003), Innovation is not Enough: Climates for Initiative and Psychological Safety, Process Innovations, and Firm Performance, „Journal of Organizational Behavior", Vol. 24, pp. 45-68. 
[5] Bariso J. (2018), Google Spent Years Studying Great Teams. These 5 Qualities Contributed the Most to Its Success. To Build a Successful Team, You Must Find the Balance between Results and Culture, https://www.inc.com/justin-bariso/ google-spent-years-studying-great-teams-these-5-qualities-contributed-most-to-their-success.html, access date: 19.02.2020.

[6] Boucher A., Sheng L., Ho C. (2018), Psychological Safety: An Essential Constituent of COMPASS, „Directions”, Vol. 3, No. 3, pp. 1-15.

[7] Brown S.P., Leigh T.W. (1996), A New Look at Psychological Climate and its Relationship to Job Involvement, Effort, and Performance, „Journal of Applied Psychology”, Vol. 81, No. 4, pp. 358-368.

[8] Carmeli A., Gitell J.H. (2009), High-quality Relationships, Psychological Safety, and Learning from Failures in Work Organizations, „Journal of Organizational Behavior”, Vol. 30, No. 6, pp. 709-729.

[9] Detert J.R., Edmondson A.C. (2011), Implicit Voice Theories: Taken-for-rules of Self-censorship at Work, „Academy of Management Journal", Vol. 54, pp. 461-488.

[10] Dionisio M., de Vargas E.R. (2020), Corporate Social Innovation: A Systematic Literature Review, „International Business Review", Vol. 29, No. 2, pp. 1-12.

[11] Dunne B.J., Greenwald J.M. (2014), Psychological Safety and Engagement: Clarity through the Lens of Social Exchange Theory, Midwest Academy of Management, Minneapolis.

[12] Edmondson A.C. (1999), Psychological Safety and Learning Behavior in Work Teams, „Administrative Science Quarterly”, Vol. 44, No. 2, pp. 350-383.

[13] Edmondson A.C. (2004), Psychological Safety, Trust, and Learning in Organizations: A Group-Level Lens, [in:] R. Kramer, K. Cook (ed.), The Russell Sage Foundation Series on Trust. Trust and Distrust in Organizations: Dilemmas and Approaches. Russell Sage Foundation, New York, pp. 239-272.

[14] Edmondson A.C., Lei Z. (2014), Psychological Safety: The History, Renaissance, and Future of on Interpersonal Construct, "Annual Review of Organizational Psychology and Organizational Behavior", Vol. 1, pp. 23-43.

[15] Flick U. (2012), Projektowanie badania jakościowego, Wydawnictwo Naukowe PWN, Warszawa.

[16] George J., Zhou J. (2007), Dual Tuning in a Supportive Context: Joint Contributions of Positive Mood, Negative Mood, and Supervisory Behaviors to Employee Creativity, „Academy of Management Journal", Vol. 50, No. 3, pp. 605-622.

[17] Gibbs G. (2011), Analizowanie danych jakościowych, Wydawnictwo Naukowe PWN, Warszawa.

[18] Hobfoll S.E. (1989), Conservation of Resources: A New Attempt at Conceptualizing Stress, „American Psychologist”, Vol. 44, No. 3, pp. 513-524.

[19] Huang C.C., Jiang P.C. (2012), Exploring the Psychological Safety of R↔D Teams: An Empirical Analysis in Taiwan, „Journal of Management and Organization”, Vol. 18, No. 2, pp. 175-192.

[20] Kahn W.A. (1990), Psychological Conditions of Personal Engagement and Disengagement at Work, „Academy of Management Journal", Vol. 33, No. 4, pp. 692-724.

[21] Kark R., Carmeli A. (2009), Alive and Creating: The Mediating Role of Vitality and Aliveness in the Relationship between Psychological Safety and Creative Work Involvement, „Journal of Organizational Behaviour., Vol. 30, No. 6, pp. 785-804

[22] Marczak S. (2015), Ocena zaangażowania społeczeństwa $w$ tworzenie danych przestrzennych $w$ Polsce na przykładzie projektu OpenStreetMap, „Roczniki Geomatyki”, Tom XIII, Zeszyt 3, Nr 69, s. 239-253.

[23] Nafei W.A. (2016), Organizational Silence: A Barrier to Organizational Change, „Case Studies Journal”, Vol. 5, No. 9, pp. 86-105.

[24] Newman A., Donohue R., Eva N. (2017), Psychological Safety: A Systemic Review of the Literature, „Human Resource Management Review”, Vol. 27, No. 3, pp. 521-535.

[25] O’Donovan R., McAuliffe E. (2020), A Systematic Review Exploring the Content and Outcomes of Interventions to Improve Psychological Safety, Speaking up and Voice Behaviour, „BMC Health Services Research”, Vol. 20, No. 1, pp. 1-11.

[26] Pacheco D.C., de Serpa Arruda A.I.D., Caldeira S.N. (2015), Silence in Organizations and Psychological Safety: A Literature Review, „European Scientific Journal”, Special Edition, pp. 293-308.

[27] Pearsall M.J., Ellis A.P.J. (2011), Thick as Thieves: The Effects of Ethical Orientation and Psychological Safety on Unethical Team Behavior, „Journal of Applied Psychology”, Vol. 96, No. 2, pp. 401-411.

[28] PwC (2014), Managing People in a Changing World, Pricewaterhouse Coopers, Société coopérative (Luxembourg), https://www.pwc.lu/en/sustainability/docs/pwc-hrs.pdf, access date: 24.02.2020.

[29] Schein E.H., Bennis W.G. (1965), Personal and Organizational Change trought Group Methods: The Laboratory Approach, John Wiley and Sons, New York.

[30] Siemsen E., Roth A.V., Balasubramanian S., Anand G. (2009), The Influence of Psychological Safety and Confidence in Knowledge on Employee Knowledge Sharing, „Manufacturing \& Service Operations Management", Vol. 11, No. 3, pp. 429-447.

[31] Wu T.C., Liu C.W., Lu M.C. (2007), Safety Climate in University and College Laboratories: Impact of Organizational and Individual Factors, „Journal of Safety Research”, Vol. 38, No. 1, pp. 91-102.

\section{Psychological Safety in the Organisation from the Perspective of Management and Quality Sciences}

\section{Summary}

Psychological safety of employees is seen as one of the key factors leading to both improvement of the efficiency and development of modern organisations. Therefore, the concept of psychological safety is currently being implemented by many organisations treating their employees as a capital which determines firms' competitiveness and innovation. Nevertheless, in Poland, psychological safety is a poorly recognised and rarely studied issue. Thus, the article aims to identify and present the main threads raised in research on psychological safety in the organisation from the perspective of the discipline of management 
and quality science. The objectives of the article have been achieved based on the desk research covering the years 1994-2020. Based on the analysis, four main areas of research on psychological safety in the organisation in the area of management and quality sciences have been identified: (1) the essence of psychological safety; (2) areas of psychological safety in organizations; (3) the impact of psychological safety on the organization; (4) mechanisms underlying psychological safety in organizations. The conducted research focused mainly on the group / team level, and the research issues at this level concentrated primarily on performance in the organisation or factors influencing psychological safety. Performance, information sharing, and creativity have been the most common areas of research in the studies regarding the impact of psychological safety on organizations.

\section{Keywords}

psychological safety, organization 